удк 340.49

DOI https://doi.org/10.32851/tnv-tech.2021.5.5

\title{
STUDY OF THE PARAMETERS OF THE FERMENTATION PROCESS OF NATURAL JUICES
}

\author{
Rogova N.V. - Ph.D., Associate Professor at the Department of Hotel \\ and Restaurant and Resort Information \\ Higher Educational Establishment of Ukoopspilka \\ "Poltava University of Economics and Trade" \\ ORCID ID: 0000-0002-5189-9058 \\ Volod'ko O.V. - Ph.D., Associate Professor at the Department of Hotel \\ and Restaurant and Resort Information \\ Higher Educational Establishment of Ukoopspilka \\ "Poltava University of Economics and Trade" \\ ORCID ID: 0000-0003-1387-181X
}

The purpose of the article is to highlight the results of the study of the parameters of the fermentation process of birch sap to obtain on its basis new types of natural blended sap.

The general characteristics and expediency of using natural juices are given. It is noted that the juices contain in unchanged form and in optimal amounts useful substances for the body (vitamins, easily digestible organic minerals, trace elements, enzymes, natural sugars, alkali metals, natural medicines, plant hormones, antibiotics, etc). In particular, birch sap, due to the rich composition of macro-and micronutrients, is an effective remedy for many diseases and a useful vitamin drink to strengthen the immune system and nervous system, which is especially true during the pandemic COVID-19.

The results of experimental determination of titrated acidity of fermented birch sap are highlighted. Calculations of titrated acidity were performed according to the equation of kinetics, taking into account the kinetic coefficients determined according to experimental data. The results showed good closeness to the experimental values. The value of the relative error is in the range of 0.24-9.45\%, which is quite acceptable for the mathematical description of biochemical processes. The linear direct proportional nature of the dependence of the titrated acidity of fermented birch sap on the initial concentration of sugars is determined: the rate of lactic acid accumulation during fermentation is very low at the beginning of fermentation, higher in the middle stage and reaches the highest values at the end of fermentation.

Given the described nature of the laws of kinetics of lactic acid accumulation, a rational duration of the fermentation process in 4 days is recommended, which allows to achieve a sufficiently high degree of lactic acid accumulation. A further increase in duration leads to a significant slowdown in the fermentation process. It is noted that even after heat treatment and storage, the developed types of juices have significant microbicidal activity, reducing the number of microorganisms in the studied strains by 30 or more times.

Key words: birch sap, biochemical processes, fermentation process, titrated acidity, lactic acid.

Рогова Н.В., Володько О.В. Дослідження параметрів процесу ферментування натуральних соків

Мета статті полягає у висвітленні результатів дослідження параметрів проиесу ферментування березового соку для отримання на його основі нових видів натуральних купажованих соків.

Наведено загальну характеристику та доиільність вжсивання натуральних соків. Зазначено, що соки містять у незмінному вигляді та в оптимальній кількості корисні для організму речовини (вітаміни, легкозасвоювані органічні мінерали, мікроелементи, ензими, природні иукри, лужні метали, натуральні лікарські речовини, рослинні гормони, антибіотики тощо). Зокрема, березовий сік завдяки багатому складу макро- $і$ мікроелементів є ефективним засобом від багатьох хвороб та корисним вітамінним напоєм для зміцнення імунітету й нервової системи, щзо особливо актуально під час пандемії COVID-19. 
Висвітлено результати експериментального визначення титрованої кислотності ферментованого березового соку. Розрахунки титрованої кислотності проведено за рівнянням кінетики з урахуванням визначених за експериментальними даними кінетичних коефіиієнтів. Результати показали гарну наближеність до експериментальних значень. Величина порівняної похибки дорівнює 0,24-9,45\%, щуо ичілком прийнятно для математичного опису біохімічних процесів. Визначено лінійний прямо пропорційний характер залежності титрованої кислотності ферментованого березового соку від початкової концентрацї иукрів: ивидкість накопичування молочної кислоти під час ферментування дуже низька на початку прочесу, більша - в середній стадї та досягає найбільших значень наприкіниі ферментування.

Враховуючи описаний характер закономірностей кінетики накопичування молочної кислоти, рекомендована раџіональна тривалість проиесу ферментування впродовж 4 діб, шоо дозволяє досягти досить високого ступеня накопичення молочної кислоти. Подальше ж збільшення тривалості призводить до значного уповільнення процесу ферментаціі. Відзначено, щзо навіть після термічної обробки та зберігання розроблені види соків мають значну мікробоцидну активність, знижуючи кількість мікроорганізмів досліджуваних итамів у понад 30 разів.

Ключові слова: березовий сік, біохімічні процееси, процес ферментації, титрована кислотність, молочна кислота.

The study found that there is a significant potential for domestic producers of juices and juice drinks, the use of which is limited by such factors, as the low level of purchasing power of Ukrainian consumers and the growing level of competition in this segment of the commodity market and modern technologies for harvesting raw materials for the production of birch sap with the extended term of its preservation and substantiation of recommendations on the production of new types of natural blended juices on the basis of fermented birch sap therefore, that the processing industry until recently used for canning only freshly produced birch sap [1]. At the same time, its shelf life before processing is extremely limited, because at high temperatures, it can ferment spontaneously, even during transportation. Unfortunately, the healing product of birch lasts only 3-4 days.

Plant juices supply energy in the form of biophotons, normalize body functions and encourage it to self-repair and produce antibodies against viruses, to diseases and colds contribute to the normalization of biochemical and acid-base balance of the blood and tissues, prevent premature aging. Vegetable juices improve digestion, stimulate the heart, endocrine glands, increase the body's overall resistance to microbes and various diseases. Juice treatment takes into account that each of them has its own, unique characteristics and a certain side effect, which, however, can be compensated by using mixtures of juices [2].

Vegetable juices, or phytosocks (Latin phyto - plant, succus - juice) - a set of cellular and extracellular juice of fresh plant organs, which is released freely (see Nectar, Pasoka, Mucus, Resins and balms) or due to damage to the plant body (Pad, Latex, Gum), or squeezed artificially. Natural juice is obtained from fresh vegetable raw materials (fruits, berries, vegetables, herbs, leaves, flowers) by pressing under high pressure, without the addition of sugar, acids, artificial colors, flavors and preservatives. They are the most useful and much more effective in the body, because they are formed and undergo a biological cycle in a plant cell, which has much in common with the cells of animals and humans. Such juices are easily and quickly (in 10-15 minutes) absorbed by the human body, are fully used to nourish the blood, regenerate and heal tissues, cleanse the body and saturate it with nutrients.

Natural juices cause almost no side effects, allergic reactions, do not accumulate in the body, act slowly, contain native BAS, show the greatest enzymatic, vitamin and volatile activity. In the case of drying, extraction and storage of vegetable raw materials 
BAS undergo certain changes under the influence of enzymatic processes and other factors.

From natural juices get juices:

- canned (stabilized) by treatment with chlorobutanol hydrate, ethyl alcohol or citric acid;

- concentrated (condensed) juices are obtained from fresh plant material in vacuum evaporators;

- dried vegetable juices are obtained by sublimation to a residual humidity of $2-3 \%$. They are more stable, free of ballast substances and are used for quick and easy preparation of medicines;

- pigmented juices contain, in addition to active metabolites, organic dyes (see plant pigments).

For therapeutic purposes, juices are used only in doses, under the supervision of a physiotherapist.

One of the most popular cooling and diet drinks is falcon - birch sap., or birch tears [3].

From ancient chronicles it is known that the collection of birch saps (juicers) was carried out in the princely days. This fishery is not forgotten in our time.

Birch sap is a popular cooling and diet drink that is consumed not only by humans but also by bees, which improves the quality of honey.

The pharmacological properties of birch sap are the ability to dissolve urinary stones, most of phosphate and carbonate origin.

It is believed that it heals the blood, stimulates metabolism, strengthens the nervous system, acts as a diuretic. Prolonged use helps to remove kidney stones. It is used as a vitamin, antisclerotic, anthelmintic and tonic. Birch sap is useful in scurvy, gout and rheumatism, diseases of the kidneys, liver and gastrointestinal tract. It can be drunk by diabetics, but without added sugar [4].

More than 5 million liters of birch sap are harvested annually in Ukraine. It heals the blood, activates metabolism, strengthens the nervous system, normalizes the liver, gastrointestinal tract (GI tract), promotes the excretion of salts, urinary and kidney stones, have a vitamin, antisclerotic, anthelmintic effect, nourishes the skin, enhances it, smoothes wrinkles removes pigment spots.

Until recently, the processing industry used only freshly produced birch sap for canning. At the same time, its shelf life before processing is extremely limited, because at high temperatures, it can ferment spontaneously, even during transportation. Unfortunately, the healing product of birch lasts only 3-4 days [7].

Juices are made according to the technology used in the canning industry for the production of blended juices. Fermented birch sap is mixed with prepared juices and sugar according to the recipe and heated to $35-40^{\circ} \mathrm{C}$. Finished canned food was sent for storage in the warehouse.

To determine the duration of fermentation $(\tau)$ of birch sap, which can provide the required titrated acidity of birch sap due to the accumulation of lactic acid, depending on the initial concentration of sugars $c_{0}$ it is necessary to investigate the patterns of fermentation. It is known that the kinetics of the fermentation process depend on many factors. The most important of them are the initial concentration of sugars $\mathrm{c}_{0}$ and the duration of the fermentation process $\tau$. To reduce energy consumption for the fermentation process, it is desirable to carry out without heating the juice at room temperature.

From the literature $[5 ; 6]$ it is known that the kinetics of most biochemical processes have significant nonlinearity in duration, and can be described by various mathematical 
models, which include a number of kinetic coefficients, which are determined by experimental data.

Taking into account the above, a plan of experiments on indicators was made, given in the table. 1. The same table shows the results of experimental determination of the titrated acidity of fermented birch sap.

Results. The obtained experimental data were approximated by a kinetic equation close to the known mathematical model of Moser [5]:

$$
T=T_{m} c_{0}^{a} \frac{\tau^{n}}{k_{s}+\tau^{n}},
$$

$\mathrm{T}$ is the titrated acidity, $\%$;

$\mathrm{Tm}$ is the maximum value of the titrated acidity that can be reached at the end of the fermentation process, $\%$.

$\mathrm{c}_{0}$ - initial concentration of sugars in birch sap, $\%$;

$\tau$ is the duration of fermentation, hours;

a, ks, $\mathrm{n}-$ kinetic coefficients determined by experimental data.

Table 1

Experimental plan and results of research of kinetics of birch sap fermentation process

\begin{tabular}{|c|c|c|c|c|c|}
\hline \multirow{2}{*}{$\begin{array}{c}\text { Experiment } \\
\text { number }\end{array}$} & \multicolumn{2}{|c|}{ Experimental conditions } & \multicolumn{2}{|c|}{ Titrated acidity,\% } & \multirow{2}{*}{$\begin{array}{c}\text { Relative } \\
\text { tweak, \% }\end{array}$} \\
\cline { 2 - 5 } & $\mathbf{C}, \mathbf{\%}$ & $\boldsymbol{\tau}$, hour. & experiment & calculation & 6 \\
\hline 1 & 2 & 3 & 4 & 5 & - \\
\hline 2 & 1,4 & 0 & 0,00 & 0,00 & 5,45 \\
\hline 3 & 1,4 & 1 & 0,12 & 0,13 & 1,93 \\
\hline 4 & 1,4 & 2 & 0,48 & 0,49 & 7,10 \\
\hline 5 & 1,4 & 3 & 0,78 & 0,84 & 2,55 \\
\hline 6 & 1,4 & 4 & 1,09 & 1,06 & 4,21 \\
\hline 7 & 1,4 & 5 & 1,25 & 1,20 & 1,48 \\
\hline 8 & 1,4 & 6 & 1,26 & 1,28 & - \\
\hline 9 & 0,9 & 0 & 0,00 & 0,00 & 9,33 \\
\hline 10 & 0,9 & 1 & 0,1 & 0,09 & 7,75 \\
\hline 11 & 0,9 & 2 & 0,38 & 0,35 & 0,24 \\
\hline 12 & 0,9 & 3 & 0,6 & 0,60 & 1,48 \\
\hline 13 & 0,9 & 4 & 0,75 & 0,76 & 2,14 \\
\hline 14 & 0,9 & 5 & 0,84 & 0,86 & 1,80 \\
\hline 15 & 0,9 & 6 & 0,90 & 0,92 & - \\
\hline 16 & 0,4 & 0 & 0,00 & 0,00 & 1,64 \\
\hline 17 & 0,4 & 1 & 0,05 & 0,05 & 9,45 \\
\hline
\end{tabular}

The above kinetic coefficients a, ks, $n$, which are included in the kinetic equation (1), were determined by us from experimental data by the method of least squares $[5 ; 6]$, taking into account which the kinetic equation took the following form:

$$
T=1,131 c_{0}^{0,754} \frac{\tau^{2,410}}{10,521+\tau^{2,410}}
$$


The calculations were performed in an MS Excel spreadsheet environment using the "Solution Search" procedure.

Calculations of titrated acidity, performed according to the obtained equation of kinetics, showed good approximation to the experimental values, the value of the relative error is in the range of $0.24-9.45 \%$, which is quite acceptable for the mathematical description of biochemical processes.

Geometric interpretation of the dependence of the titrated acidity of fermented birch sap on the sugar concentration and duration of the fermentation process, obtained by equation (2), is shown in Fig. 1.

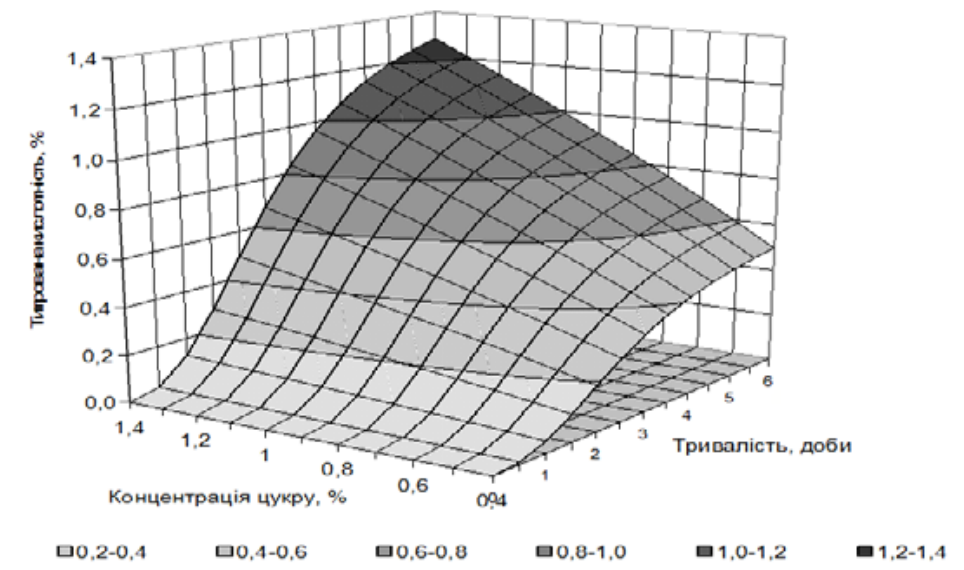

Fig. 1. The dependence of the titrated acidity of the fermented birch sap from sugar concentration and duration fermentation process

The figure clearly shows that the dependence of the titrated acidity of fermented birch sap on the duration of the fermentation process has an s-shaped character, typical of most fermentation processes: at the beginning of fermentation the process speed is very low, in the middle stage it increases rapidly. It is also seen that with increasing initial concentration of sugars $\mathrm{c}_{0}$, the fermentation process proceeds faster and during the same duration of the process the titrated acidity increases significantly.

The dependence of the titrated acidity of fermented birch sap on the initial concentration of sugars $\mathrm{c}_{0}$, regardless of the duration of fermentation, is linear and directly proportional. However, it can be noted that the rate of lactic acid accumulation during fermentation depending on the initial concentration of sugars $\mathrm{c}_{0}$ is also different at different stages of the process: very low at the beginning of fermentation, higher in the middle stage and reaches the highest values at the end of fermentation.

Given the descriptive nature of the laws of kinetics of lactic acid accumulation can be recommended as a rational duration of the fermentation process in 4 days. At this duration, a sufficiently high degree of accumulation of lactic acid is achieved. A further increase in duration leads to a significant slowdown in the fermentation process, which is not rational.

\section{BIBLIOGRAPHY:}

1. Мельник I.В. Тенденції розвитку українського ринку соків. Облік $і$ фінанси АПК. URL: http://magazine.faaf.org.ua/tendencii-rozvitku-ukrainskogo-rinku-sokiv. html (дата звернення: 06.09.2021 p.). 
2. Дослідження ринку соків в Україні - прогнози на 2020 p. i ретроперспектива. Компанія Pro Consulting. URL: https://pro-consulting.ua/ua/ pressroom/issledovanie-rynka-sokov-v-ukraine-prognozy-na-2020g-i-retrospektiva (дата звернення: 06.09.2021 p.).

3. Дослідження біологічної активності ферментованого березового соку / Н.В. Рогова та ін. Вісник ХНТУСГ ім. П. Василенко «Сучасні напрями технології та механізації процесів переробних і харчових виробнищтв». 2006. Вип. 45. C. 371-376.

4. Rohova N.V, Volod'ko O.V. Nutritional and biological value of juices, their effect on the human body and their importance in nutrition. Вчені записки Таврійського національного університету ім. В.І. Вернадського. Серія «Технічні науки». 2020. C. $83-87$.

5. Рогова Н.В. Вплив температури на термін ферментування і прозорість березового соку. Нові технології й обладнання харчових виробництв : міжвуз. наук.практ. семінар, м. Полтава, 19 квітня 2018 р. ПУЕТ, 2018. С. 21-23.

6. Rogova N.V. Manufacture technology of fermented birch sap and new combined products based. Actual problems of the world today: materials of collective monograph / N.V. Rogova, O.V. Volodko. London, 2019. P. 252-267.

7. Харчова біологічна цінність соків, їх дія на організм людини та їхнє значення в харчуванні / Н.В. Рогова та ін. Science and society : 9th Intern. conf., Hamilton, Canada, 1st February, 2019. Hamilton, 2019. P. 95-98.

\section{REFERENCES:}

1. Mel'nik, I.V. (2021) Tendencii rozvitku Ukrains'kogo rinku sokiv [Trends in the development of the Ukrainian juice market]. Oblik i finansy APK. URL: http://magazine. faaf.org.ua/tendencii-rozvitku-ukrainskogo-rinku-sokiv.html. [in Ukrainian]

2. Doslidzhennja rinku sokiv v Ukraini-prognozi na 2020 r. i retrospektiva [Research of the juice market in Ukraine - forecasts for 2020 and retrospective]. Kompaniia Pro Consulting. URL: https://pro-consulting.ua/ua/pressroom/issledovanie-rynka-sokov-vukraine-prognozy-na-2020g-i-retrospektiva. [in Ukrainian]

3. Rogova, N.V. et al. (2006). Doslidzhennja biologichnoi aktivnosti fermentovanogo berezovogo soku [Study of biological activity of fermented birch sap]. Visnik HNTUSG im. P. Vasilenko "Suchasni naprjami tehnologii ta mehanizacii procesiv pererobnih $i$ harchovih virobnictv”. Issue 45. P. 371-376. Kharkiv. [in Ukrainian]

4. Rohova, N.V., Volod'ko, O.V. (2020) Kharchova i biolohichna tsinnist sokiv, yikh diia na orhanizm liudyny ta znachennia $\mathrm{v}$ kharchuvanni [Nutritional and biological value of juices, their effect on the human body and their importance in nutrition]. Vcheni zapysky Tavriiskoho natsionalnoho universytetu im. V.I. Vernadskoho. Ser. Tekhnichni nauky. P. 83-87. Kyiv. [in Ukrainian]

5. Rohova, N.V. (2018) Vplyv temperatury na termin fermentuvannia i prozorist berezovoho soku [The effect of temperature on the fermentation period and transparency of birch sap]. Interuniversity scientific-practical seeds: "Novi tekhnolohii i obladnannia kharchovykh vyrobnytstv”. P. 21-23. Poltava : PUET. [in Ukrainian]

6. Rogova, N.V., Volod'ko, O.V. (2019) Tekhnologiya proizvodstva berezovogo sbrozhennogo soka i novykh kombinirovannykh produktov na yego osnove [Manufacture technology of fermented birch sap and new combined products based] : materials of collective monograph: "Aktual'nyye problemy mira segodnya”. P. 252-267. London. [in English]

7. Rogova, N.V., Volodko, O.V., Bichkov, Ja.M., Ribakova, S.S. (2019). Harchova biologichna cinnist' sokiv, ih dija na organizm ljudini ta znachennja $\mathrm{v}$ harchuvanni [Nutritional biological value of juices, their effect on the human body and their importance in nutritio]. Proceedings of the Conference Title: IX Mizhnarodna konferentsiia "Nauka i suspilstvo”. P. 95-98. Hamilton. [in English] 